\title{
IDENTIFIKASI AFEKSI PATERNAL PADA AYAH DARI ANAK USIA DINI DI KOTA KUPANG
}

\author{
${ }^{1}$ Fitriany Karunia Muh. Wangge, ${ }^{2}$ Friandry Windisany Thoomaszen, \\ ${ }^{3}$ Beatriks Novianti Kiling-Bunga \& ${ }^{4}$ Indra Yohanes Kiling \\ 1e-mail: fitrianywangge@gmail.com \\ 1,3Pendidikan Guru Pendidikan Anak Usia Dini Universitas Nusa Cendana \\ ${ }^{2}$ Konseling Pastoral Sekolah Tinggi Agama Kristen Negeri Kupang \\ ${ }^{4}$ Institute of Resource Governance and Social Change \\ Jl. Adisucipto Penfui, Nusa Tenggara Timur
}

\begin{abstract}
Abstrak: Ayah yang melakukan pengasuhan secara emosional atau afeksi paternal yang baik pada anak usia dini memiliki beragam dampak positif. Hal ini diduga belum diterapkan sepenuhnya oleh para ayah di Indonesia Timur, khususnya Kota Kupang. Penelitian ini bertujuan untuk mengetahui sejauh mana afeksi paternal serta kaitannya dengan faktor-faktor demografik. Sampel yang digunakan pada penelitian ini sebanyak 158 sampel di Kota Kupang yang masing-masing memiliki karakteristik sebagai seorang ayah yang mempunyai anak usia berkisar nol sampai dengan delapan tahun. Teknik dalam penentuan sampel menggunakan teknik insidental sampling. Penelitian yang dilakukan dari November 2015 sampai dengan Maret 2016 ini kuesioner yang terdiri atas 10 item pernyataan. Data penelitian dianalisis menggunakan statistik deskriptif. Hasil temuan pada penelitian ini menunjukkan bahwa para ayah di Kota Kupang memiliki afeksi paternal yang tinggi. Hal ini dilihat dari hasil sebaran data yang menggambarkan bahwa dari 158 sampel afeksi paternal berada pada kategori tinggi. Ini membuktikan bahwa para ayah di kota Kupang telah menyadari tentang pentingnya keterlibatan mereka dalam pengasuhan secara emosional. Selain itu hasil penelitian ini menemukan beberapa pola dari afeksi paternal ketika ditinjau dari beberapa faktor demografik. Temuan positif ini perlu ditindaklanjuti oleh pemangku kepentingan terkait di Kota Kupang untuk terus menguji kebenaran terkait pengasuhan ayah serta mendorong dan meningkatkan kapasitas ayah dalam melakukan pengasuhan. Peneliti selanjutnya dapat menggali secara kualitatif untuk memahami pola ayah dalam mengasuh dari sisi emosional, ini akan membantu menjelaskan proses dan makna dibalik interaksi pengasuhan ayah dan anak usia dini.
\end{abstract}

Kata-kata Kunci: Keterlibatan ayah, pengasuhan, afeksi paternal, anak usia dini.

\section{IDENTFICATION OF PATERNAL AFFECTION ON THE FATHER OF EARLY AGED CHILD IN KUPANG CITY}

Abstract: The father parenting an early aged child with emotion or good paternal affection has various positive effects. However, presumably the fathers in Eastern Indonesia has not implemented it well. This research aims at discovering paternal affection and its relations with demographic factors. Samples used in this research totaled 158 fathers each of which had a child of $0-8$ years old. The samples were determined by employing incidental sampling technique. The research conducted as from November 2015 through March 2016 used questioner with 10 statement items. The collected data was analyzed with descriptive statistics. The findings showed that the fathers in Kupang City had high paternal affection supporting by the fact that 158 samples of paternal affection were categorized high. The finding proves, the fathers in Kupang City fully realize their important involvement in emotional parenting. The research also discovered several patterns of paternal affection based on the some demographic factors. The positive research findings should be followed up by concerned parties in Kupang City. They also should verify the findings and motivate as well as improve the fathers' capacity in emotional parenting. This action will assist to clarify the process and the meaning behind the interaction between father's parenting and early aged child.

Keywords: father's involvement, parenting, paternal affection, early aged child 


\section{PENDAHULUAN}

Keluarga sebagai satuan unit sosial terkecil merupakan lingkungan pendidikan yang paling utama dan pertama. Keluarga juga merupakan kelompok pertama yang menjadi tempat untuk meletakkan dasar kepribadian (Hasan, 2011). Selain itu, keluarga merupakan lingkungan yang paling bertanggung jawab terhadap keberhasilan pendidikan anak. Hal ini dikarenakan anak adalah anugerah Tuhan kepada orangtua, anak mendapatkan pendidikan pertama dari orangtua, serta orangtualah yang mengetahui karakter anaknya (Graha, 2007, dalam Amini, 2015). Dalam memberikan pendidikan, orangtua selalu berusaha memberikan yang terbaik bagi anak-anaknya. Hal ini dapat dilihat dari berbagai cara yang dilakukan, mulai dari mengasuh anak sejak bayi dan balita, hingga memilihkan sekolah untuk anak. Berkaitan dengan hal tersebut untuk mencapai keberhasilan dalam pendidikan anak kedua orangtua harus saling bekerja sama melibatkan diri. Pentingnya keterlibatan orangtua antara lain dikemukakan oleh Bronfenbrenner (1976) (dalam Morrison, 2008) menyatakan bahwa tanpa keterlibatan keluarga dalam hal ini kedua orangtua, intervensi program pendidikan anak usia dini akan melemah. Untuk itu diperlukan keterlibatan kedua orangtua dalam pendidikan anak mulai dari mengasuh hingga memilihkan sekolah dan lain-lain.

Pada era modernisasi ini, pengasuhan yang awalnya lebih identik dengan tanggung jawab seorang ibu kini juga merupakan tanggung jawab seorang ayah. Hal ini didukung dengan banyaknya jumlah ibu yang bekerja maka cenderung tugas pengasuhan anak diserahkan kepada ayah (Ernawati, 2009). Walaupun cara pengasuhan yang dilakukan ayah berbeda dengan ibu, namun ayah juga memiliki peran dalam pengasuhan yang sangat berpengaruh pada perkembangan anak, yaitu: (1) Ayah mengajarkan/mendorong kebebasan, secara umum ayah cenderung kurang protektif, mendorong eksplorasi dan pengambilan risiko, serta merupakan model perilaku agresif ataupun asertif; (2) Ayah meluaskan pandangan anak, ayah mengenalkan dunia luar melalui pekerjaan mereka; (3) Ayah merupakan pendisiplin yang tegas, hanya memberi sedikit permakluman dan cenderung menuntut banyak dari anak-anak mereka untuk tiap tahapnya; dan (4) Ayah adalah model bagi anak laki-laki (Grimm-Wassil, 1994, dalam Wahyuningrum, 2011).

Pada dasarnya keterlibatan ayah dalam pengasuhan diartikan sebagai seberapa besar usaha yang dilakukan oleh seorang ayah dalam berpikir, merencanakan, merasakan, memperhatikan, memantau, mengevaluasi, mengkhawatirkan serta berdoa bagi anaknya. Anak yang ayahnya terlibat dalam pengasuhan dirinya akan memiliki kemampuan sosial dan kognitif yang baik, serta kepercayaan diri yang tinggi (Palkovitz, 2002). Adapun dimensi keterlibatan ayah dalam pengasuhan diukur dengan (Fox \& Bruce, 2001): (1) responsivity; sejauh mana ayah menggunakan kehangatan, kasih sayang, dan sikap suportif; (2) harshness; sejauh mana ayah menggunakan sikap galak, menghukum, dan pendekatan inkonsistem; (3) behavioral engagement; sejauh mana ayah terlibat aktif dengan anak; dan (4) affective involvement; sejauh mana ayah menginginkan dan menyanyangi anak.

Berkaitan dengan dimensi-dimensi keterlibatan ayah dalam pengasuhan, pada penelitian ini penulis akan membahas secara khusus tentang affective involvement atau dapat disebut dengan paternal affection (afeksi paternal). Selain pemahaman afeksi paternal menurut Fox dan Bruce (2001) di atas, afeksi paternal diartikan oleh Palkovitz (2002) sebagai salah satu dari 14 kategori keterlibatan ayah dalam pengasuhan yang berkaitan dengan memberikan kasih sayang dan sentuhan emosi. Dari kedua pendapat di atas maka dapat disimpulkan bahwa afeksi paternal merupakan dimensi keterlibatan ayah dalam pengasuhan secara emosional yang berkaitan dengan menginginkan, memberikan kasih sayang dan sentuhan emosi. Adapun contoh perilaku dari afeksi paternal yaitu: (1) Kebiasaan ayah mengecup anak saat berangkat ataupun pulang kerja, (2) Ayah yang selalu memberikan kado yang bermanfaat saat anak ulang tahun, (3) Ayah yang selalu menenangkan anak dengan pelukan saat anak merasa takut, dan (4) Ayah yang selalu berbincangbincang dengan anak sekedar menanyakan keadaanya, dan lain sebagainya.

Penelitian menunjukkan dampak pengasuhan ayah yang baik pada kemampuan bahasa dan kognitif anak usia dini (Shannon dkk., 2002; Ryan, Martin \& Brooks-Gunn, 2006). Penelitian lain menemukan bahwa pengasuhan yang sensitif 
terhadap perilaku anak memiliki hubungan dengan kemampuan kognitif, perialku serta sosioemosional yang lebih optimal (Mesman, Van ljzendoorn, \& Bakermans-Kranenburg, 2012). Dari hasil penelitian di atas jelas menggambarkan tentang dampak-dampak positif yang terjadi jika ayah terlibat dalam pengasuhan anak secara emosional. Namun, pada kenyataanya berdasarkan pengamatan penulis di Kota Kupang masih banyak para ayah yang berasumsi bahwa sesungguhnya pengasuhan anak merupakan tugas ibu sedangkan ayah bertugas mencari nafkah. Selain itu, masih banyak pula para ayah yang enggan menunjukkan sisi emosionalnya pada anak misalnya mencium, membelai, memeluk, bahkan berbincang-bincang dengan anak hanya sekedar menanyakan kabar atau keadaannya. Hal ini memperlihatkan indikasi perbedaan antara hasil penelitian yang mayoritas dilakukan di negara maju dengan keadaan yang berada di negara berkembang seperti Indonesia. Dengan adanya asumsi di atas maka akan berdampak buruk bagi kehidupan anak dimana anak akan memiliki masalah seperti identitas yang tidak lengkap; rasa ketakutan yang tidak teratasi; kemarahan yang tidak terkendali; depresi yang tidak terdiagnosa; perjuangan melawan rasa kesepian; kesalahpahaman seksualitas dan identitas yang terganggu; kegagalan dalam hal keterampilan memecahkan masalah (Oliver, 1995, dalam Elia, 2000).

Berdasarkan fenomena-fenomena di atas serta didukung dengan minimnya literatur-literatur atau penelitian yang membahas secara khusus tentang afeksi paternal maka penulis bertujuan untuk meneliti secara deskriptif sejauh mana keterlibatan ayah di Kota Kupang dalam pengasuhan secara emosional. Memahami kualitas afeksi paternal dapat menolong untuk merencanakan upaya prevensi kekerasan kepada anak maupun perdagangan anak dalam rangka mendukung Kota Kupang sebagai kota layak anak. Penelitian ini juga diharapkan bisa menjadi titik tolak bagi peneliti lain untuk melanjutkan penelitian lanjutan yang lebih mendalam dengan menggunakan pendekatan metode lain demi memahami lebih lanjut pengasuhan ayah terhadap anak usia dini.

\section{METODE PENELITIAN}

Penelitian ini merupakan pendekatan deskriptif kuantitatif. Metode penelitian ini digunakan untuk mendapatkan gambaran ketelibatan ayah dalam pengasuhan secara emosional. Populasi penelitian ini adalah para ayah yang berada di kota Kupang. Teknik pengambilan sampel menggunakan teknik sampling insidental yang mana penentuan sampel berdasarkan kebetulan yaitu siapa saja yang secara kebetulan bertemu dengan peneliti dapat digunakan sebagai sampel jika cocok sebagai sumber data (Sugiyono, 2010). Sampel yang digunakan pada penelitian ini berjumlah 158 sampel yang masingmasing memiliki karakteristik sebagai seorang ayah yang memiliki anak berusia diantara 0-8 tahun. Waktu penelitian adalah dari November 2015 sampai dengan Maret 2016.

Penelitian ini menggunakan instrumen skala Likert berupa kuesioner tentang keterlibatan ayah dalam pengasuhan secara emosional yang disusun untuk memperoleh data demografik (pendidikan ayah, pekerjaan ayah, suku ayah, umur ayah, umur anak, urutan lahir anak) dan juga untuk mengukur afeksi paternal. Adapun item-item kuesioner berupa 10 pernyataan yang akan mengungkapkan tentang afeksi paternal yaitu: (1) saya berbincang-bincang dengan anak sekedar menanyakan keadaannya, (2) saya menenangkan anak saat bersedih sambil membelainya, (3) saya memberikan hadiah yang bermanfaat saat anak ulang tahun,(4) ketika bermain bersama anak saya selalu memeluknya dengan erat, (5) saya memberikan contoh perilaku yang baik kepada anak, (6) saya memberikan kecupan kepada anak saat bertemu dan berpisah, (7) saya menegur dengan lembut ketika anak melakukan kesalahan, (8) sebelum berpergian saya selalu melambaikan tangan kepada anak, (9) saya mengetahui setiap hal yang anak inginkan, dan (10) saya menggendong anak saat bertemu.

Pengukuran item kuesioner tersebut menggunakan skala likert dengan pilihan jawaban: (1) sangat sesuai, (2) sesuai, (3) jarang, (4) tidak sesuai, (5) sangat tidak sesuai. Untuk melakukan analisis data, pada penelitian ini menggunakan teknik statistik deskriptif yaitu statistik yang digunakan untuk menganalisis data dengan cara mendeskripsikan data yang telah terkumpul sebagaimana adanya tanpa bermaksud membuat kesimpulan yang berlaku untuk umum/generalisasi (Sugiyono, 2010). Pendapat serupa menyebutkan bahwa analisis statistik deskriptif merupakan teknik olah data 
dengan teknik dan rumus statistik deskriptif untuk menggambarkan keadaan suatu obyek atau variabel tertentu sehingga dapat diperoleh kesimpulan umum (Agung, dalam Wahyuni, Asri \& Suniasih, 2014).

\section{HASIL DAN PEMBAHASAN}

\section{Hasil Penelitian}

Setelah melakukan pengolahan data dengan tabulasi silang berdasarkan isian data demografik beserta isian pada item-item kuesioner, hasil penelitian akan dijabarkan dalam empat buah tabel. Dapat dilihat di tabel 1 bahwa dari 158 partisipan penelitian, sebanyak $32,91 \%$ memiliki tingkat afeksi paternal tinggi, sedangkan $31,01 \%$ peserta lainnya memiliki tingkat afeksi paternal yang sangat tinggi. Hal ini memperlihatkan bahwa para ayah di Kota Kupang menunjukkan kemampuan pengasuhan anak dari sisi emosional yang tinggi dan sangat tinggi.

Tabel 1. Afeksi Paternal Dilihat dari Tingkat Pendidikan Ayah

\begin{tabular}{|c|c|c|c|c|c|c|c|c|}
\hline \multirow{2}{*}{$\mathrm{K}$} & \multicolumn{6}{|c|}{ Pendidikan } & \multirow{2}{*}{ Jml } & \multirow{2}{*}{$\%$} \\
\hline & SD & SMP & SMA & DIII & s1 & S3 & & \\
\hline ST & 4 & 5 & 24 & 3 & 13 & 0 & 49 & 31,01 \\
\hline$T$ & 1 & 3 & 28 & 3 & 17 & 0 & 52 & 32,91 \\
\hline $\mathbf{S}$ & 4 & 7 & 17 & 1 & 6 & 1 & 36 & 22,80 \\
\hline $\mathbf{R}$ & 2 & 2 & 7 & 0 & 2 & 0 & 13 & 8,22 \\
\hline SR & 1 & 0 & 3 & 0 & 4 & 0 & 8 & 5,06 \\
\hline $\mathrm{Jml}$ & 12 & 17 & 79 & 7 & 42 & 1 & 158 & 100 \\
\hline$\%$ & 7,59 & 10,75 & 50 & 4.43 & 26,58 & 0,63 & 100 & \\
\hline
\end{tabular}

Keterangan

K : Kategori

ST : Sangat Tinggi

T : : Tinggi

S : : Sedang

$\mathrm{R} \quad$ : Rendah

SR : Sangat Rendah
Tabel 1 juga menunjukkan bahwa dari 158 partisipan jumlah partisipan tertinggi yakni setengahnya berada pada tingkat pendidikan sekolah menengah atas dan terendah berada pada tingkat pendidikan strata 3 sebesar $0,63 \%$. Dilihat dari kategori afeksi paternal, meski mayoritas baru mengenyam tingkat pendidikan setingkat sekolah menengah atas, namun ayah di Kota Kupang telah menunjukkan kemampuan mengasuh anak secara emosional dengan baik dan sangat baik.

Selanjutnya, dari 158 orang partisipan, jumlah partisipan terbanyak bekerja sebagai wiraswasta dengan jumlah 55 orang $(34,8 \%)$ dan terendah bekerja sebagai pensiunan PNS, TNI dan petani masing-masing sebanyak 2 orang. Dilihat dari kategori afeksi paternal, memiliki proporsi terbesar ketiga dengan $19,6 \%$, semua ayah dengan pekerjaan swasta memiliki tingkat afeksi paternal dari rendah ke sangat tinggi. Tidak ada ayah pekerja swasta yang memiliki tingkat afeksi paternal yang rendah dan sangat rendah, berbeda dengan ayah pegawai negeri swasta dan ayah wiraswasta, masih ada yang memiliki afeksi paternal rendah dan sangat rendah. Angka tersebut ditambah dengan fakta bahwa proporsi terbesar pada ayah pekerja swasta yakni 15 orang ada di tingkat sangat tinggi, menunjukkan bahwa rata-rata ayah pekerja swasta memiliki kualitas afeksi paternal yang sangat baik. Untuk lebih jelasnya mengenai hasil data hasil penelitian tersebut dapat dilihat pada tabel 2 berikut.

Tabel 2. Afeksi Paternal Dilihat dari Pekerjaan Ayah

\begin{tabular}{|c|c|c|c|c|c|c|c|c|c|c|c|c|c|}
\hline \multirow[b]{2}{*}{ Kategori } & \multicolumn{11}{|c|}{ Pekerjaan } & \multirow[b]{2}{*}{$\mathrm{Jml}$} & \multirow[b]{2}{*}{$\%$} \\
\hline & Swasta & PNS & Wiraswasta & Supir & Guru & POLRI & Buruh & Petani & Nelayan & TNI & $\begin{array}{l}\text { Pensiunan } \\
\text { PNS }\end{array}$ & & \\
\hline Sangat Tinggi & 15 & 8 & 13 & 0 & 1 & 4 & 4 & 1 & 2 & 0 & 1 & 49 & 31,01 \\
\hline Tinggi & 11 & 12 & 20 & 1 & 1 & 3 & 2 & 0 & 1 & 1 & 0 & 52 & 32,91 \\
\hline Sedang & 5 & 7 & 14 & 4 & 0 & 2 & 1 & 0 & 1 & 1 & 1 & 36 & 22,80 \\
\hline Rendah & 0 & 1 & 6 & 0 & 1 & 1 & 1 & 1 & 2 & 0 & 0 & 13 & 8,22 \\
\hline Sangat Rendah & 0 & 4 & 2 & 0 & 0 & 0 & 1 & 0 & 1 & 0 & 0 & 8 & 5,06 \\
\hline $\mathrm{Jml}$ & 31 & 32 & 55 & 5 & 3 & 10 & 9 & 2 & 7 & 2 & 2 & 158 & 100 \\
\hline$\%$ & 19,6 & 20,25 & 34,8 & 3,16 & 1,89 & 6,3 & 5,69 & 1,26 & 4,43 & 1,3 & 1,3 & 100 & \\
\hline
\end{tabular}

Selanjutnya, hasil penelitian menunjukkan bahwa bahwa dari 158 partisipan jumlah partisipan terbanyak merupakan suku Timor 65 orang dan terendah berada pada suku Sumbawa dan Semau masing-masing satu orang. Hal ini terkait dengan kenyataan bahwa penelitian dilakukan di Kota Kupang yang berada di dataran Timor. Sebaran data memperlihatkan bahwa jumlah ayah dengan 
suku Flores memiliki kualitas afeksi paternal yang seimbang pada tingkat tinggi dan sangat tinggi (12 partisipan). Ini memperlihatkan kecenderungan bahwa ayah suku Flores memiliki afeksi paternal yang berkisar pada kategori tinggi dan sangat tinggi. Selengkapnya, data hasil penelitian tersebut dapat dilihat pada tabel 3 berikut.

Tabel 3. Afeksi Paternal Dilihat dari Suku Ayah

\begin{tabular}{|c|c|c|c|c|c|c|c|c|c|c|c|c|c|c|c|}
\hline \multirow{2}{*}{ Kategori } & \multicolumn{13}{|c|}{ Pekerjaan } & \multirow{2}{*}{$\mathrm{Jml}$} & \multirow{2}{*}{$\%$} \\
\hline & Al & $\mathrm{Tm}$ & Rt & $\mathrm{FI}$ & $\mathrm{Sm}$ & $\mathrm{Sb}$ & $\mathrm{Se}$ & $\mathrm{Bm}$ & $\mathrm{Bt}$ & $\mathrm{Bg}$ & $\mathrm{TI}$ & Jw & $\mathrm{Am}$ & & \\
\hline Sangat Tinggi & 5 & 20 & 4 & 12 & 1 & 0 & 0 & 1 & 0 & 1 & 2 & 2 & 2 & 49 & 31,01 \\
\hline Tinggi & 2 & 24 & 5 & 12 & 1 & 0 & 1 & 1 & 2 & 1 & 0 & 1 & 2 & 52 & 32,91 \\
\hline Sedang & 3 & 15 & 8 & 7 & 1 & 1 & 0 & 0 & 0 & 0 & 0 & 0 & 0 & 36 & 22,80 \\
\hline Rendah & 2 & 5 & 0 & 1 & 1 & 0 & 0 & 0 & 1 & 1 & 0 & 2 & 0 & 13 & 8,22 \\
\hline Sangat Rendah & 4 & 1 & 0 & 1 & 0 & 0 & 0 & 0 & 0 & 1 & 0 & 1 & 0 & 8 & 5,06 \\
\hline Jml & 16 & 65 & 17 & 33 & 4 & 1 & 1 & 2 & 3 & 4 & 2 & 6 & 4 & 158 & 100 \\
\hline$\%$ & 10,1 & 41,1 & 10,7 & 20,8 & 2,5 & 0,6 & 0,6 & 1,2 & 1,8 & 2,5 & 1,2 & 3,7 & 2,5 & 100 & \\
\hline
\end{tabular}

Keterangan:

Al: Alor

Se: Semau

$\begin{array}{lll}\text { Tm: Timor } & \text { Rt: Rote } & \text { Fl: Flores } \\ \text { Bm: Bima } & \text { Bt: Batak } & \text { Bg: Bugis }\end{array}$

Hasil penelitian mengenai afeksi paternal dilihat dari urutan lahir anak dapat dilihat pada tabel 4 berikut.

Tabel 4. Afeksi Paternal Dilihat dari Urutan Lahir Anak

\begin{tabular}{|c|c|c|c|c|c|c|}
\hline \multirow{2}{*}{ Kategori } & \multicolumn{4}{|c|}{ Urutan Anak } & \multirow{2}{*}{$\mathrm{Jml}$} & \multirow{2}{*}{$\%$} \\
\hline & Sulung & Tengah & Bungsu & Tunggal & & \\
\hline $\begin{array}{l}\text { Sangat } \\
\text { Tinggi }\end{array}$ & 13 & 13 & 13 & 10 & 49 & 31,01 \\
\hline Tinggi & 10 & 9 & 17 & 16 & 52 & 32,91 \\
\hline Sedang & 7 & 10 & 15 & 4 & 36 & 22,80 \\
\hline Rendah & 2 & 1 & 10 & 0 & 13 & 8,22 \\
\hline $\begin{array}{l}\text { Sangat } \\
\text { Rendah }\end{array}$ & 1 & 0 & 7 & 0 & 8 & 5,06 \\
\hline $\mathrm{Jml}$ & 33 & 33 & 62 & 30 & 158 & 100 \\
\hline$\%$ & 7,59 & 10,75 & 50 & 4.43 & 100 & \\
\hline
\end{tabular}

Ketika mencermati Tabel 4 di atas, terlihat bahwa dari 158 partisipan, jumlah terbanyak memiliki anak usia dini urutan bungsu 62 orang. Sisa ayah yang lain memiliki anak usia dini dengan urutan sulung, tengah dan tunggal tersebar dengan cukup merata dengan jumlah masing-masing 33 orang, 33 orang dan 30 orang. Karena sebaran jumlah partisipan terbilang merata, maka bisa disimpulkan bahwa ayah dengan anak usia dini pada urutan sulung dan tengah $(39,39 \%)$ secara proposi lebih besar memiliki tingkat afeksi paternal yang sangat tinggi dibanding dengan ayah dengan anak usia dini pada urutan bungsu $(20,96 \%)$ dan tunggal $(30 \%)$.

\section{Pembahasan}

Pada dasarnya keterlibatan ayah dalam

\begin{tabular}{|c|c|}
\hline Sm: Sumba & Sb: Sumbawa \\
\hline
\end{tabular}

pengasuhan diartikan sebagai seberapa besar usaha yang dilakukan oleh seorang ayah dalam berpikir, merencanakan, merasakan, memperhatikan, memantau, mengevaluasi, memikirkan serta berdoa bagi anaknya. Anak yang ayahnya terlibat dalam pengasuhan dirinya, akan memiliki kemampuan sosial dan kognitif yang baik, serta kepercayaan diri yang tinggi (Palkovitz, 2002). Salah satu bentuk keterlibatan ayah dalam pengasuhan yaitu afeksi paternal. Berdasarkan hasil penelitian di atas dapat dibahas bahwa afeksi paternal para ayah yang ada di Kota Kupang cukup baik. Hal ini dapat dilihat dari hasil sebaran data yang diperoleh bahwa dari 158 partisipan rerata afeksi paternal berada pada kategori tinggi. Lebih lanjut, rerata kedua berada pada tingkat sangat tinggi. Ini membuktikan bahwa ayah-ayah di Kota Kupang sebagian besar sudah mengetahui betapa pentingnya mengasuh anak usia dini dari sisi emosional dalam masa tumbuh kembang anak, serta mampu menerapkannya dalam keluarga masing-masing.

Temuan ini bertolak belakang dengan anggapan nasional, mengingat belum lama ini Ketua Komisi Nasional Perlindungan Anak Indonesia menyatakan Nusa Tenggara Timur (NTT) dalam kondisi darurat kekerasan anak (Timor Express, 2015). Selain itu juga kajian lain juga menyebutkan bahwa di daerah lain di NTT seperti di Sumba Timur, kejadian kekerasan kepada anak masih rawan dan kerap terjadi, terutama pada anak yang secara struktur sosial kurang menguntungkan (Kiling \& Bunga, 2014a; Kiling \& Bunga, 2014b). Orangtua 
yang memiliki afeksi paternal tinggi seharusnya akan menjauhi pola asuh keras seperti pemberian hukuman fisik yang dapat memicu terjadinya tindak kekerasan pada anak. Hal ini bisa jadi disebabkan oleh karena penelitian ini dilakukan di Kota Kupang yang adalah ibukota provinsi, di mana akses informasi serta taraf ekonomi dan pendidikan notabene cenderung lebih baik dibanding daerah non ibukota provinsi. Selain itu pula, tentu ada faktor social desirability yang dapat mempengaruhi orangtua untuk mengisi kuesioner dengan jawaban yang lebih diterima di lingkungan sosial. Penelitian lanjutan perlu dilakukan untuk mengecek kembali hasil penelitian ini.

Berdasarkan hasil penelitian ditemukan juga beberapa pola hasil tabulasi silang dari faktorfaktor demografik terhadap keterlibatan ayah dalam pengasuhan. Walaupun lebih banyak memiliki tingkat pendidikan sekolah menengah atas, ayah di Kota Kupang menunjukkan pemahaman serta kemampuan untuk mengasuh anak usia dininya dari sisi emosional sang anak. Pada dasarnya, orangtua yang memiliki tingkat pendidikan tinggi akan memahami perkembangan jiwa anak dan memberikan pengarahan akhlak yang baik (Willis, 1994, dalam Awik, 2004). Apalagi tingkat pendidikan menengah atau sekolah menengah atas merupakan tingkat pendidikan yang mempersiapkan peserta didik menjadi anggota masyarakat yang memiliki kemampuan mengadakan hubungan timbal balik dengan lingkungan dan sosial budaya (Ihsan, 2001). Dengan demikian, jika ayah-ayah yang berada pada tingkat pendidikan sekolah menengah atas memiliki afeksi paternal yang tinggi maka sepatutnya ayah yang memiliki tingkat pendidikan yang lebih tinggi dari sekolah menengah atas akan memiliki tingkat afeksi paternal yang sama atau bahkan lebih tinggi. Hal ini dikonfirmasi oleh data yang menunjukkan bahwa ayah dengan pendidikan strata 1 lebih banyak $(40,47 \%)$ memiliki tingkat afeksi paternal yang tinggi.

Selain pendidikan, penelitian ini juga melihat pola yang muncul dari afeksi paternal dan faktor pekerjaan dari ayah. Pekerjaan adalah suatu aktivitas yang dilakukan manusia untuk menghasilkan sesuatu dalam memenuhi kebutuhan hidup dan meningkatkan taraf hidupnya. Untuk para ayah pekerjaan adalah aktivitas utama mereka dalam keluarga. Penelitian pada orangtua anak usia dini dengan disabilitas di Kota Kupang menyebutkan bahwa pekerjaan orangtua berpengaruh pada rasa kepercayaan diri sang anak (Dolu, Bunga \& Kiling, 2014). Meskipun banyak waktu yang terpakai dalam pekerjaan, hal ini bukan suatu halangan bagi para ayah di Kota Kupang untuk ikut berpartisipasi dalam pengasuhan anak. Hal ini didukung oleh hasil penelitian yang menunjukkan bahwa ayah-ayah yang bekerja khususnya bekerja sebagai pegawai swasta memiliki kualitas afeksi paternal yang sangat baik. Meski pekerjaan sebagai swasta memiliki tingkat kesulitan serta jam kerja yang beragam, penelitian ini menunjukkan bahwa ayah yang bekerja swasta mampu menyeimbangkan antara pekerjaan dan keluarga. Hal ini sangat dibutuhkan karena peran orangtua sangat dibutuhkan dalam perkembangan anak usia dini seperti misal dalam aspek komunikasi (Ita, Bunga \& Kiling, 2014). Penelitian selanjutnya dapat secara lebih dalam mengeksplorasi pola asuh yang dilakukan oleh ayah pegawai swasta yang memiliki anak usia dini.

Dari hasil penelitian di atas menunjukkan bahwa selain pendidikan dan pekerjaan ternyata afiliasi pada suku tertentu menunjukkan pola yang menarik secara statistik. Hal ini dibuktikan dari hasil penelitian yang menyatakan bahwa para ayah yang bersuku Flores memiliki afeksi paternal yang berkisar pada kategori tinggi dan sangat tinggi. Pola seperti ini tidak ditemukan pada suku lain, memperlihatkan bahwa ayah dari anak usia dini bersuku Flores memiliki kecenderungan untuk lebih memahami pengasuhan secara emosional yang baik untuk anaknya. Apakah hasil ini memiliki kaitan dengan fakta bahwa mayoritas masyarakat suku Flores beragama Katolik, atau secara topografi memiliki tanah yang lebih subur dibanding pulau lain di NTT (Badan Pusat Statistik, 2015) perlu dibuktikan dengan lanjutan dengan desain penelitian yang berbeda.

Selanjutnya selain suku, urutan lahir anak juga berpengaruh terhadap tinggi rendahnya afeksi paternal pada ayah di Kota Kupang. Urutan lahir dalam penelitian ini dikategorikan menjadi empat bagian yaitu anak sulung, anak tengah, anak bungsu dan anak tunggal. Sesuai dengan hasil penelitian di atas menunjukkan bahwa afeksi paternal sangat tinggi lebih banyak ditemukan pada ayah yang memiliki anak usia dini dengan urutan sulung dan tengah. Menurut Alfred Adler (dalam Wulanningrum, 2009) urutan lahir dalam keluarga memiliki peranan penting dalam perkembangan anak selanjutnya. Dalam kehidupan sehari-hari banyak 
fenomena yang mengatakan bahwa anak sulung diasosiasikan sebagai anak yang cepat dewasa, berwibawa dan lain lain. Sedangkan anak bungsu diasosiasikan sebagai anak yang manja, tidak tegas serta lemah lembut. Anak tengah dan anak tunggal juga diasosiasikan sebagai anak yang manja dan sebagainya (Gunarsa, 2007, dalam Wulanningrum, 2009). Hasil penelitian ini menunjukkan bahwa anak sulung dan tengah cenderung lebih banyak memperoleh pengasuhan emosi yang baik oleh ayah mereka. Hal tersebut bisa disebabkan oleh karena ayah sebagai orangtua masih dalam fase bulan madu sebagai orangtua baru bersama anak sulung dan anak tengah mereka. Asumsi tersebut tentu perlu ditanggapi dengan penelitian lebih lanjut di masa depan.

Penelitian ini menemukan beragam pola yang muncul dari data demografik serta kualitas afeksi internal pada ayah dari anak usia dini di Kota Kupang. Keterbatasan dari penelitian ini salah satunya seperti yang sudah disebutkan adalah terkait dengan social desirability yang membuat hasil dari penelitian belum tentu sesuai dengan keadaan yang sebenarnya. Langkah untuk mereduksi kecenderungan untuk memilih jawaban yang tidak sesuai dengan keadaan sebenarnya perlu diterapkan pada penelitian serupa di masa depan demi meningkatkan kualitas penelitian secara keseluruhan.

\section{PENUTUP}

\section{Kesimpulan}

Berdasarkan hasil penelitian di atas dapat disimpulkan bahwa afeksi paternal para ayah di kota Kupang, NTT tergolong baik. Hal ini didukung dari hasil penelitian yang menyatakan bahwa dari 158 partisipan lebih dari setengah yakni sekitar 63 , $92 \%$ memiliki tingkat afeksi paternal yang tinggi dan sangat tinggi. Ayah dengan tingkat pendidikan SMA, bekerja sebagai pegawai swasta, bersuku Flores serta memiliki anak usia dini dengan urutan sulung dan tengah secara umum memiliki afeksi paternal yang baik. Riset lanjutan dibutuhkan untuk mengecek kebenaran penelitian ini karena bertolak belakang dengan keadaan NTT secara umum yang masih rawan dengan kejadian kekerasan kepada anak. Selain itu, kajian lanjutan juga dibutuhkan demi menguji beberapa pola yang telah didiskusikan di pembahasan penelitian.

\section{Saran}

Adapun saran dari penelitian yang telah dilakukan untuk para ayah, diharapkan penelitian ini dapat menjadi motivasi untuk melibatkan diri dalam mengasuh anak untuk membantu mengembangkan perkembangan anak yang lebih baik. Serta bagi para peneliti selanjutnya, diharapkan penelitian ini dapat menjadi sumber atau referensi bagi penelitiannya, terlebih khusus disarankan untuk menguji dengan pendekatan kualitatif proses interaksi ayah dan anak usia dini dalam pengasuhan sehingga dapat diketahui kebenaran dari hasil penelitian termasuk pola-pola yang muncul dari faktor demografik dan afeksi paternal.

\section{DAFTAR PUSTAKA}

Amini, M. (2015). Profil keterlibatan orangtua dalam pendidikan anak usia TK. Jurnal IImiah VISI PPTK-PAUDNI, 10(1), 9-20.

Awik, H. (2004). Pengaruh tingkat pendidikan dan pola asuh orangtua terhadap prestasi anak. Jurnal Pendidikan, 3(3), 267-276.

Badan Pusat Statistik (2015). Nusa Tenggara Timur dalam angka 2014. Kupang: Badan Pusat Statistik.

Dolu, E. R. Y., Bunga, B. N., Kiling, I. Y. (2014). Gambaran penerimaan orangtua anak usia dini berkebutuhan khusus di Nusa Tenggara Timur. Jurnal Pendidikan Teknologi dan Vokasi, 13(2), 45-49.

Ernawati, M. (2009). Model keterlibatan ayah dalam pengasuhan. Artikel IImiah. Salatiga: Sekolah Tinggi Agama Islam Negri.
Elia, H. (2000). Peran ayah dalam mendidik anak. VERITAS: Jurnal Teologi dan Pelayanan, 1(1), 105-113.

Fox, G. L., \& Bruce, C. (2001). Conditional fatherhood: Identity theory and parental investment theory as alternative sources of explanation of fathering. Journal of Marriage and Family, 63, 394-403.

Hasan, M. (2011). Pendidikan anak usia dini. Yogyakarta: DIVA Press

Ihsan, F. (2001). Dasar-dasar kependidikan. Jakarta: Rineka Cipta

Ita, K. N., Bunga, B. N., Kiling, I. Y. (2014). Gambaran komunikasi anak usia dini tunagrahita di Nusa Tenggara Timur. Jurnal Pendidikan Teknologi dan Vokasi, 13(1), 59-63.

Kiling, I. Y., \& Bunga, B. N. (2014a). Urgensi positive 
parenting di Sumba Timur. In Taufiqurrahman, A. Puspitacandri, H. Khotimah, \& U. Manara (Eds.), Proceeding Seminar Nasional dan Call for Paper Ketahanan Keluarga sebagai Aset Bangsa: Family, Marriage, Parenting. "Pengelolaan Mutu Keluarga dan Perkawinan untuk Persiapan Generasi Muda Berkualitas" (pp. 836-848). Malang: Unmer Press.

Kiling, I. Y., \& Bunga, B. N. (2014b). Kompleksitas kekerasan kepada anak perempuan kasta Ata di Sumba Timur. In P. Satwiko, \& D. Listiorini (Eds.), Proceeding Senanti 2014 (pp. 63-67). Yogyakarta: Universitas Atma Jaya Yogyakarta.

Mesman, J., Van ljzendoorn, M. H., \& BakermansKranenburg, M. J. (2012). Unequal in opportunity, equal in process: Parental sensitivity promotes positive child development in ethnic minority families. Child Development Perspectives, 6, 239-250.

Morrison, G. S. (2008). Fundamentals of early childhood education, 5th ed. New Jersey: Pearson Education.

Palkovitz, R. (2002). Involved fathering and child development: Advancing our understanding of good fathering. In C. S. Tamis-LeMonda \& N. Cabrera (Eds.), Handbook of father involvement: Multidisciplinary perspectives. New Jersey: Lawrene Erlbaum Associates.

Ryan, R. M., Martin, A., \& Brooks-Gunn, J. (2006). Is one good parent good enough? Patterns of mother and father parenting and child cognitive outcomes at 24 and 36 months. Parenting: Science and Practice, 6, 211-228.

Shannon, C., Tamis-LeMonda, C., London, K.,
\& Cabrera, N. (2002). Beyond rough and tumble: Low-income fathers' interactions and children's cognitive development at 24 months. Parenting: Science and Practice, 2, 77-104.

Sugiyono. (2010). Metode penelitian kuantitatif, kualitatif \& RND. Bandung: Alfabeta

Timor Express. (2015). Komnas PA: NTT darurat kekerasan anak. Diakses 8 Maret 2016 dari http://www.timorexpress. com/20150724110356/-komnas-pa-nttdarurat-kekerasan-anak

Wahyuni, N. N. R., Asri, I. G. A. A. S., \& Suniasih, N. W. (2014). Penerapan metode demonstrasi dengan lingkungan sebagai sumber belajar untuk meningkatkan keterampilan motorik halus anak. E-journal PG-PAUD Universitas Pendidikan Ganesha, 2(1).

Wahyuningrum, E. (2011). Peran ayah (fathering) pada pengasuhan anak usia dini (sebuah kajian teoritis). Psikowacana, 10 (1\&2), 1-19.

Wulanningrum, D. N. (2009). Hubungan antara urutan kelahiran dalam keluarga dengan kecerdasan emosional pada remaja di SMA Muhammadiyah 1 Klaten. Skripsi. Fakultas IImu Kesehatan: Universitas Muhammadiyah Surakarta. Tidak diterbitkan 